\title{
Subcutaneous fat accumulation during pregnancy in a malnourished population
}

\author{
BY P. ARROYO, DEYANIRA GARCIA, C. LLERENA \\ AND SARA E. QUIROZ \\ Subjefatura de Investigación Básica, Instituto Mexicano del Seguro Social, \\ Apartado Postal 72-032, Mexico 7, D.F.
}

(Received 5 December 1977 - Accepted I I April I978)

\begin{abstract}
1. Total skinfold thicknesses (sum of seven sites) were measured in fifty-seven pregnant women with low energy and protein intake, at weeks 24,30 and 35 of gestation.

2. Women were classified in two groups (overweight and low weight), according to their weight-forheight at week 24 of gestation.

3. Half of the women did not increase, or even reduced the amount of subcutaneous fat during the observation period. The lowest mean value of total skinfold thickness was found in the low-weight women who showed a reduction of the subcutaneous fat.

4. This finding shows that a significant proportion of malnourished women do not follow the average pattern of subcutaneous fat accumulation seen in bealthy pregnant women without food intake restriction, during the second half of pregnancy.
\end{abstract}

It has been reported that the average healthy pregnant woman, without food intake restriction, deposits a fair amount of subcutaneous fat between weeks 10 and 30 of gestation and this deposition, which is greater in primiparae and in women with low initial weight, slows down after this time (Taggart, Holliday, Billewicz, Hytten \& Thomson, 1967). However, it is not known if pregnant women from populations with a high prevalence of energy-protein malnutrition and restricted food intake show the same pattern.

The present work aims to describe the magnitude and variability of the subcutaneous fat deposition during the second half of pregnacy in such a group of women of rural and urban origin.

\section{EXPERIMENTAL}

The work was conducted between June 1973 and July 1974 in Huamantla, a semi-rural county in the state of Tlaxcala. Approximately $60 \%$ of the population in Huamantlais engaged in agricultural work (Secretaría de Industria y Comercio, Mexico, 1972) and Tlaxcala had the second highest infant mortality rate in México during 1973, i.e. 80.2 infant deaths/1000 live births (Secretaría de Salubridad y Asistencia, México, 1975).

In a group of 288 consecutive pregnant women attending the local prenatal clinic for the first time, skinfold thickness was measured, according to the technique described by Taggart et al. (1967), at the following sites: triceps, biceps, scapula, costal, suprailiac, mid-thigh and knee. Measurements were taken by one single observer (D.G.) using a Harpenden skinfold calliper (John Bull British Indicators Ltd, England) with faces of $6 \times 15 \mathrm{~mm}$ and exerting a constant pressure of $10 \mathrm{~g} / \mathrm{mm}^{2}$. The procedure was carefully standardized, each measurement was made in triplicate on the left side of the body and results were averaged. The coefficients of variation between successive measurements on the same subject were similar to those reported by Taggart et al. (1967). Skinfold measurements quoted include double layers of skin and subcutaneous tissue. Results are presented in the form of 'total skinfolds' (TSF), i.e. the sum of values at the seven sites measured.

The majority of women were seen during the second half of pregnancy and at monthly 
visits thereafter. Besides skinfold thickness, height and weight were determined at the initial visit; height was measured with an anthropometer (Siber-Hegner \& Co., Zurich, Switzerland) to the nearest I $\mathrm{mm}$, the woman standing erect, with heels together, the feet at an angle of $45^{\circ}$ and the line of vision directed horizontally; body-weight of the subjects, wearing a piece of cloth, was measured on a clinical scale to the nearest $0 \cdot \mathrm{I} \mathrm{kg}$. A standard weight of the piece of cloth $(0.3 \mathrm{~kg})$ was deducted from the observed weight. Additional information regarding age, parity, birth place and husband's main occupation was obtained.

Since attendance at the clinic was quite irregular, we selected a smaller group of fiftyseven women, in whom a long-term evaluation of subcutaneous fat reserves would be possible; they met the following criteria: $(a)$ attendance at the clinic at weeks 24,30 and 35 of gestation, (b) diastolic blood pressure lower than $90 \mathrm{mmHg}$, absence of clinical oedema, and any other signs of illness at each visit, $(c)$ delivery at the clinic of a live, healthy, single baby of at least 37 weeks' gestation. For purpose of the present study, description and analysis of results will be confined to this latter group.

In order to provide a control for the initial state of fat reserves, the fifty-seven women were classified at week 24 of gestation in two groups: (I) greater than expected weight-forheight (overweight group, $n$ 26), and (2) equal or less than expected weight-for-height (low-weight group, $n$ 31). Allocation was done by comparing each subject's weight to the regression value of weight $v$. height, calculated for an independent group of forty-five women seen during weeks I9-2I gestation. This latter group represented the earliest dates of entry into the study and shared the same socio-economic characteristics of the fifty-seven women studied. The equation used was

$$
y=34 \cdot 888 \text { (height }(\mathrm{m}))+\mathrm{I} \cdot 0567,
$$

where $y$ is the expected weight-for-height $(\mathrm{kg})$. In addition to skinfold thickness, weight was recorded at each monthly visit.

Food items consumed by twenty-five of the fifty-seven women during one $24 \mathrm{~h}$ period were carefully weighed at home by trained nutritionists, between weeks 24 and 39 of gestation, with the majority of evaluations done during weeks $26-35$. The nutrient content of foods was calculated using the INCAP-ICNND food composition tables (Leung \& Flores, 1964).

\section{RESULTS}

The overweight group had an average excess weight-for-height of $6 \cdot \mathrm{I} \pm 4.7 \mathrm{~kg}$, with a median of $5.0 \mathrm{~kg}$ at week 24 . In the low-weight group an average weight deficit of $3.8 \pm 2.9 \mathrm{~kg}$ and a median of $2 \mathrm{~kg}$ in relation to the expected weight-for-height, at the same gestational age, was found. Table I shows the distribution of some demographic and social characteristics in both groups. The low-weight group was composed of more multiparae and younger women than the overweight group. The low-weight women also had a greater tendency to be married to peasants, to have had a rural origin and to be significantly shorter $\left(t_{55}=2.53\right.$; $P<0.05)$. However, except for height, these differences did not reach statistical significance.

Table 2 shows the mean values and standard deviations of energy and protein intake in a $24 \mathrm{~h}$ period of twenty-five women, according to weight groups. The variability of the protein and energy intake is large and no statistical differences were found between both groups. A substantial proportion of women had lower than recommended daily intake of energy and only a low proportion of the total protein intake was represented by animal protein (Department of Health and Social Security, 1969).

In each case the change of the TSF values from weeks 24-35 was evaluated. Since not all women showed an increase in subcutaneous fat, three subgroups were made: women who had an increase in TSF, those who had a decrease and those with no change during the 
Table I. Distribution of age, status of pregnancy, social characteristics and height of fiftyseven pregnant Mexican women according to weight-for-height

(Values in parentheses indicate percentage of total)

\begin{tabular}{|c|c|c|c|}
\hline Characteristic & $\begin{array}{l}\text { Overweight } \\
(n 26)\end{array}$ & $\begin{array}{c}\text { Low weight } \\
(n 31)\end{array}$ & $\begin{array}{l}\text { Total } \\
(n \text { 57) }\end{array}$ \\
\hline $\begin{array}{c}\text { Age (years, } \\
\text { mean } \pm \text { SD) }\end{array}$ & $25 \cdot 2 \pm 7 \cdot 6$ & $23 \cdot 9 \pm 5 \cdot I$ & $24 \cdot 3 \pm 6 \cdot 7$ \\
\hline $\begin{array}{l}\text { Parity } \\
\text { Primiparae } \\
\text { Multiparae }\end{array}$ & $\begin{array}{r}8(30.8) \\
18(69 \cdot 2)\end{array}$ & $\begin{array}{r}8(25 \cdot 8) \\
23(74 \cdot 2)\end{array}$ & $\begin{array}{l}16(28 \cdot 1) \\
41(71 \cdot 9)\end{array}$ \\
\hline $\begin{array}{l}\text { Birth place } \\
\text { Urban } \\
\text { Rural* }\end{array}$ & $\begin{array}{l}\text { I } 5(56 \cdot 7) \\
\text { I I }(43.3)\end{array}$ & $\begin{array}{l}\text { I6 (5I.6) } \\
\text { I5 }(48 \cdot 4)\end{array}$ & $\begin{array}{l}3 I\left(54^{\circ} 4\right) \\
26\left(45^{\prime} 6\right)\end{array}$ \\
\hline $\begin{array}{l}\text { Husband's occupatio } \\
\text { Peasant } \\
\text { Other }\end{array}$ & $\begin{array}{l}14(53.8) \\
12(46 \cdot 2)\end{array}$ & $\begin{array}{l}2 \text { I }(67 \cdot 7) \\
\text { IO }(32 \cdot 3)\end{array}$ & $\begin{array}{l}35(61 \cdot 4) \\
22(38 \cdot 6)\end{array}$ \\
\hline $\begin{array}{l}\text { Height }(\mathrm{mm}) \\
\text { Mean } \pm \mathrm{SD}\end{array}$ & $1483 \pm 42$ & $1456 \pm 44$ & $1468 \pm 45$ \\
\hline
\end{tabular}

* Communities of less than 5000 population.

Table 2. Mean values and standard deviations of energy and protein intake* in a 24 heriod of twenty-five Mexican women during the second half of pregnancy, grouped according to weight $\dagger$

\begin{tabular}{|c|c|c|c|c|c|c|}
\hline & \multicolumn{2}{|c|}{$\begin{array}{l}\text { Overweight } \\
(n \text { II })\end{array}$} & \multicolumn{2}{|c|}{$\begin{array}{l}\text { Low weight } \\
\quad(n \text { I4) }\end{array}$} & \multicolumn{2}{|c|}{$\begin{array}{l}\text { Total } \\
(n 25)\end{array}$} \\
\hline & Mean & SD & Mean & SD & Mean & SD \\
\hline Energy (MJ) & $8 \cdot 6$ & $2 \cdot 3$ & $9 \cdot I$ & $3 \cdot 2$ & $8 \cdot 8$ & $2 \cdot 9$ \\
\hline Animal protein $(\mathrm{g})$ & $9 \cdot 5$ & 6.8 & 10.6 & II.9 & IO. I & $9 \cdot 8$ \\
\hline Vegetable protein $(\mathrm{g})$ & $55 \cdot 3$ & $19 \cdot 3$ & $55 \cdot 7$ & $28 \cdot 9$ & $55^{.6}$ & 24.6 \\
\hline
\end{tabular}

* Recommended intake: energy Io MJ; protein $60 \mathrm{~g}$ (Department of Health and Social Security, 1969). $\dagger$ See p. 486 .

Table 3. Mean values and standard deviations of total skinfolds ( $\mathrm{mm}$ ) of fifty-seven Mexican women during the second half of pregnancy, grouped according to weight* and to change in subcutaneous fat

\begin{tabular}{|c|c|c|c|c|c|c|c|c|}
\hline & \multirow[b]{3}{*}{$\begin{array}{c}\text { Fat } \\
\text { change }\end{array}$} & \multirow[b]{3}{*}{$\begin{array}{l}\text { No. of } \\
\text { cases }\end{array}$} & \multicolumn{6}{|c|}{ Stage of pregnancy (weeks) } \\
\hline & & & \multicolumn{2}{|c|}{24} & \multicolumn{2}{|c|}{30} & \multicolumn{2}{|c|}{35} \\
\hline & & & $\overbrace{\text { Mean }}$ & SD & $\overbrace{\text { Mean }}$ & $\overrightarrow{S D}$ & $\overbrace{\text { Mean }}$ & $\widehat{S D}$ \\
\hline \multirow[t]{4}{*}{ Overweight } & Increase & 15 & I 13.8 & $23 \cdot 8$ & $122 \cdot 4$ & $26 \cdot 7$ & I $24 \cdot I$ & 27.9 \\
\hline & Decrease & 5 & $142 \cdot 9$ & $28 \cdot 8$ & $139 \cdot 2$ & $24 \cdot I$ & 133.4 & $27 \cdot I$ \\
\hline & Unchanged & 6 & I 214 & $32 \cdot 2$ & 123.2 & $35 \cdot 9$ & $120 \cdot 2$ & $32 \cdot 0$ \\
\hline & Total & 26 & 120.9 & $28 \cdot 0$ & $125 \cdot 8$ & $28 \cdot 2$ & 125.1 & 27.9 \\
\hline \multirow[t]{4}{*}{ Low weight } & Increase & 12 & $85 \cdot 0$ & $14 \cdot 1$ & $95 \cdot 9$ & $16 \cdot 9$ & $96 \cdot 9$ & $18 \cdot 5$ \\
\hline & Decrease & 10 & $82 \cdot 3$ & $13 \cdot 7$ & $78 \cdot 0$ & $14 \cdot 8$ & $74 \cdot 6$ & 14.6 \\
\hline & Unchanged & 9 & $79 \cdot 6$ & $21 \cdot 4$ & $82 \cdot 1$ & $22 \cdot 4$ & $79 \cdot 6$ & $21 \cdot 3$ \\
\hline & Total & $3 \mathrm{I}$ & $82 \cdot 6$ & 16.0 & $86 \cdot 1$ & 19.2 & 8477 & 20.3 \\
\hline
\end{tabular}


Table 4. Mean values and standard deviations of weight $(\mathrm{kg})$ of fifty-seven Mexican women during the second half of pregnancy, grouped according to weight ${ }^{*}$ and to change in subcutaneous fat

\begin{tabular}{|c|c|c|c|c|c|c|c|}
\hline \multirow[b]{3}{*}{ Fat change } & \multirow[b]{3}{*}{$\begin{array}{l}\text { No. of } \\
\text { cases }\end{array}$} & \multicolumn{6}{|c|}{ Stage of pregnancy (weeks) } \\
\hline & & \multicolumn{2}{|c|}{24} & \multicolumn{2}{|c|}{30} & \multicolumn{2}{|c|}{35} \\
\hline & & $\overbrace{\text { Mean }}$ & SD & Mean & SD & Mean & $\widehat{\mathrm{SD}}$ \\
\hline $\begin{array}{l}\text { Overweight } \\
\text { Increase } \\
\text { Decrease } \\
\text { Unchanged }\end{array}$ & $\begin{array}{r}15 \\
5 \\
6\end{array}$ & $\begin{array}{l}58 \cdot 0 \\
63 \cdot 4 \\
57 \cdot 0\end{array}$ & $\begin{array}{l}3 \cdot 8 \\
7 \cdot 3 \\
4 \cdot 8\end{array}$ & $\begin{array}{l}59 \cdot 7 \\
65 \cdot 3 \\
58 \cdot 6\end{array}$ & $\begin{array}{l}4 \cdot 5 \\
7 \cdot 2 \\
5 \cdot 3\end{array}$ & $\begin{array}{l}61 \cdot 2 \\
65 \cdot 3 \\
58 \cdot 9\end{array}$ & $\begin{array}{l}4.0 \\
7.0 \\
6.6\end{array}$ \\
\hline Total & 26 & $58 \cdot 8$ & $5 \cdot 2$ & $60 \cdot 5$ & $5 \cdot 6$ & $61 \cdot 5$ & $5 \cdot 5$ \\
\hline $\begin{array}{l}\text { Low-weight } \\
\text { Increase } \\
\text { Decrease } \\
\text { Unchanged }\end{array}$ & $\begin{array}{r}12 \\
10 \\
9\end{array}$ & $\begin{array}{l}48 \cdot 2 \\
47 \cdot 1 \\
49 \cdot I\end{array}$ & $\begin{array}{l}4 \cdot 0 \\
3 \cdot 7 \\
2 \cdot 7\end{array}$ & $\begin{array}{l}49 \cdot 7 \\
48 \cdot 9 \\
51 \cdot 7\end{array}$ & $\begin{array}{l}4 \cdot 0 \\
3 \cdot 9 \\
3 \cdot 2\end{array}$ & $\begin{array}{l}51 \cdot 3 \\
49 \cdot 8 \\
51 \cdot 9\end{array}$ & $\begin{array}{l}4 \cdot I \\
4 \cdot 5 \\
2 \cdot 7\end{array}$ \\
\hline Total & $3 I$ & $48 \cdot I$ & $3 \cdot 6$ & $50 \cdot 0$ & 3.8 & $51 \cdot 0$ & 3.9 \\
\hline
\end{tabular}

observation period. We considered that there was no change in TSF when differences were within limits of the observed variation within subjects. Tables 3 and 4 show the number of cases as well as the mean values and standard deviations of total skinfolds and weight of subgroups according to weight-for-height and pattern of fat change. Both weight groups had a number of cases in which there were no changes or there was even a reduction in skinfold thickness; however, the proportion was larger in the low weight group, although it did not reach statistical significance. In the overweight group, the women who showed a reduction of the TSF from weeks 24-35, had the highest mean values of the whole series, while the corresponding low-weight subgroup showed the lowest mean values. At week 35 there was a significant average difference in TSF between low-weight women who increased their skinfold thickness and those who showed a reduction of $22.3 \mathrm{~mm}\left(t_{20}=2.95 ; P<\right.$ $0.01)$. When a change occurred, whether it was an increase or decrease, it was most noticeable between weeks 24 and 30, and at central locations, i.e. scapula, costal, suprailiac and midthigh. The women who increased their TSF in both weight groups had greater weight increments than the other subgroups, but no significant differences emerged.

\section{DISCUSSION}

The state of reserves, as judged by the initial classification of weight-for-height at week 24 , showed great variability and positive skewness. This classification proved very useful since important differences in fat accumulation patterns were observed. A larger proportion of women with low initial TSF did not accumulate subcutaneous fat and in some cases they even decreased their reserves. This finding contrasts with reported studies on healthy, pregnant women who show considerable increase in skinfold thickness persisting until approximately week 30 (Taggart et al. 1967).

It is possible that our observation reflects the existence of an important restriction of energy intake in low-weight Huamantlan women at a time when requirements are greatest. Although determination of $24 \mathrm{~h}$ food intake does not necessarily reflect regular consumption, the results presented support this contention. Furthermore, Emerson, Poindexter \& Kothari (1975) have found that accumulation of fat during pregnancy depends on food intake, as 
it does in non-pregnant women. The decrease in subcutaneous fat during the period in which faster accumulation should be occurring probably indicates that low-weight women with the greatest food restriction use basal reserves to meet their requirements during gestation. As stated, the low-weight women in our study were mainly young multiparae belonging to a low economic stratum of the population, composed of unskilled peasants. With respect to the overweight women, the observed reduction of TSF could be interpreted as a result of a voluntary food restriction, although we do not have evidence to support this hypothesis.

Evaluation of the nutritional status of rural pregnant women from underdeveloped countries is difficult in terms of weight increment, because it is an index with low sensitivity that does not necessarily reflect changes in body composition and it requires early and regular attendance at prenatal clinics. Measurement of fat reserves using anthropometric techniques during the period of rapid accumulation, i.e. between 24 and 30 weeks in these populations, could be a more practical and useful index of nutritional status at a period when preventive measures could still be applied. Since energy restriction during pregnancy is probably a major cause of a high incidence of low-birth-weight babies, it seems important to relate the state of fat reserves in the mother to the resulting weight of the newborn (Lechtig, Yarbrough, Delgado, Habicht, Martorell \& Klein, I975).

The authors are grateful to Drs F. Zacarías and A. Parra for helpful discussion and to Miss Martha Coronado for assistance in the dietary study. This study was partly supported by Programa Nacional de Alimentación, CoNaCyT.

\section{REFERENCES}

Department of Health and Social Security (1969). Recommended Intakes of Nutrients for the United Kingdom. London: HM Stationery Office.

Emerson, K., Jr., Poindexter, E. L. \& Kothari, M. (1975). Obstet. Gynecol. 45, 505.

Lechtig, A., Yarbrough, Ch., Delgado, H., Habicht, J. P., Martorell, R. \& Klein, R. E. (1975). Am. J. clin. Nutr. 28, 1223.

Leung, W. T. W. \& Flores, M. (1964). INCAP-ICNND. Tabla de Composición de Alimentos para uso en América Latina, 2nd ed. México: Editorial Interamericana, S.A.

Secretaría de Industria y Comercio, México (1972). IX Censo General de Población, 1970. Mexico City: Secretaría de Industria y Comercio, México.

Secretaría de Salubridad y Asistencia, México (1975). Estadisticas vitales de los Estados Unidos Mexicanos. 1973. Mexico City: Secretaria de Salubridad y Asistencia, Mexico.

Taggart, N. R., Holliday, R. M., Billewicz, W. Z., Hytten, F. E. \& Thomson, A. M. (I967). Br. J. Nutr. 21, 439. 